RESEARCH ARTICLE

\title{
South-west Sri Lanka: A floristic refugium in South Asia
}

\author{
Nimal Gunatilleke ${ }^{1, *}$, Savitri Gunatilleke ${ }^{1}$ and Peter Shaw Ashton ${ }^{2}$
}

${ }^{1}$ University of Peradeniya, Sri Lanka.

${ }^{2}$ Harvard University, USA, and Royal Botanic Gardens, Kew, UK.

\author{
Received: 09/08/2017; Accepted: 15/09/2017
}

Abstract: In South Asia, south-west Sri Lanka alone represents
the sole surviving perhumid region where Mixed Dipterocarp
Forests (MDF) harbour a number of relict signature taxa providing
evidence of ancient plant migration routes from Gondwana to
perhumid Far Eastern Sunda land, at least partially via southern
Laurasia. Palynological and phylogenetic evidence now confirm
that the Malesian rain forest flora overwhelmingly immigrated
from tropical Africa/Madagascar and South Asia along an ever-
wet equatorial corridor sometime before the collision of the
Indian Plate with the Southern Laurasian coast in middle Eocene
(c. 45 Ma). This ever-wet climatic and geological history has
led to the evolution of a characteristic species composition and
dynamics within SW Sri Lanka's rain forest communities, which
exhibit remarkable patterns of species distribution and habitat
specialization, and which parallel those of Far Eastern sister taxa.

We here examine the patterns of floristic variation in each of three MDF sites using classification and ordination methods to analyse tree data collected in 62 random plots, each 0.25 ha, along an altitudinal gradient. In addition, a 25 ha forest dynamics plot (FDP) was established in the Sinharaja World Heritage Site, within the CTFS-ForestGEO network that addresses issues related to community ecology and phylogenetics incorporating large-scale biogeographic patterns of major clades of both plants and animals.

In the above studies, ecologically distinct floristic assemblages were revealed, i) among the three MDF sites as well as, ii) among the ridge-, slope-, and valley habitats within each forest site. In the FDP too, $>80 \%$ of the 125 species, with individuals $>1 \mathrm{~cm}$ dbh and $>100$ individuals per species, are significantly more associated with one or more of eight topographic habitat categories than in others. These results suggest that ecological ranges and dispersion of tree species in SW Sri Lanka is primarily mediated by soil water and nutrient levels in topographically different catenal habitats mirroring those in the Far East.

Many of these species are threatened relict endemics, and their distribution patterns have important conservation implications. Their spatial distributional features provide useful criteria in sitespecies matching or environmental filtering in forest restoration efforts.

Keywords: Sri Lanka-Western Ghats biodiversity hotspot, Out of India hypothesis, South-west Sri Lanka, floristic refugium, phytogeography, Mixed Dipterocarp Forest.

\section{INTRODUCTION}

South Asia represents the surviving part of a continental plate which initially rifted from east Africa of the Gondwanan megacontinent as the Antarctica-India-SeychellesMadagascar plate in the late Jurassic period c.150 Ma. Next, India-Madagascar separated from Antarctica ca. 130 Ma, India-Seychelles from Madagascar c. 84-96 Ma and India from Seychelles c. $65 \mathrm{Ma}$ (Raven and Axelrod, 1974; Morley, 2000; Briggs, 2003). The Indian plate eventually collided with the southern coast of the northern Laurasian continent between $55 \mathrm{Ma}-45 \mathrm{Ma}$, thereafter being crushed and partially subducted (Raven and Axelrod, 1974; Morley, 2000; Ali \& Aitchison, 2008). It had traversed from warm temperate through dry, then seasonally wet and equatorial tropical climates to land, once again, under tropical seasonality (Morley, 2000; Ashton, 2014). During its equatorial transit, shallow seas and freshwater peat swamps covered central areas, successively from $25^{\circ}$ to $10^{\circ} \mathrm{N}$. Their fossil wood and pollen reveals a southern retreat of an already rich rain forest tree flora, similar to that of the modern hyper-diverse Sunda mixed dipterocarp forest, which is now confined in South Asia to a tiny, 10,000 $\mathrm{km}^{2}$ patch in SW Sri Lanka, which itself must anticipate a final demise over future geological time (Ashton, 2014; Conti et al., 2002; Morley, 2000; Prasad et al., 2009, Rust et al. , 2010) (Figure 1).

Here, we first review paleontological evidence for past climatic and floristic change in South Asia, and their implications for the current Sri Lankan and Far Eastern Floras. We then interpret the results of recent community ecological studies, focusing on the mixed dipterocarp forests of SW Sri Lanka, within a broader understanding of tropical Asian phytogeographic history.

Information on evolutionary history and phylogenetic relationships among species are being increasingly used to address questions of community assembly including processes that determine community species richness and structure (Wiens and Donoghue, 2004; Wiens, 2012). Recent studies have focused on the roles of competitive interactions, environmental filtering, or alternatively neutral effects in influencing community composition (Cavender-Bares et al., 2009; Emerson and Gillespie, 2008; Wiens, 2012). These approaches now permit community ecologists to relate short-term local processes to regional and even global processes that occur over deep evolutionary time scales (Ackerly, 2003, 2004; Ricklefs, 1987, 2004; Mittelbach et al., 2007; Donoghue, 2008; Emerson and Gillespie, 2008; Graham and Fine, 2008). Elucidation of how these processes at different scales interact to integrate local processes (e.g. coexistence, environmental 


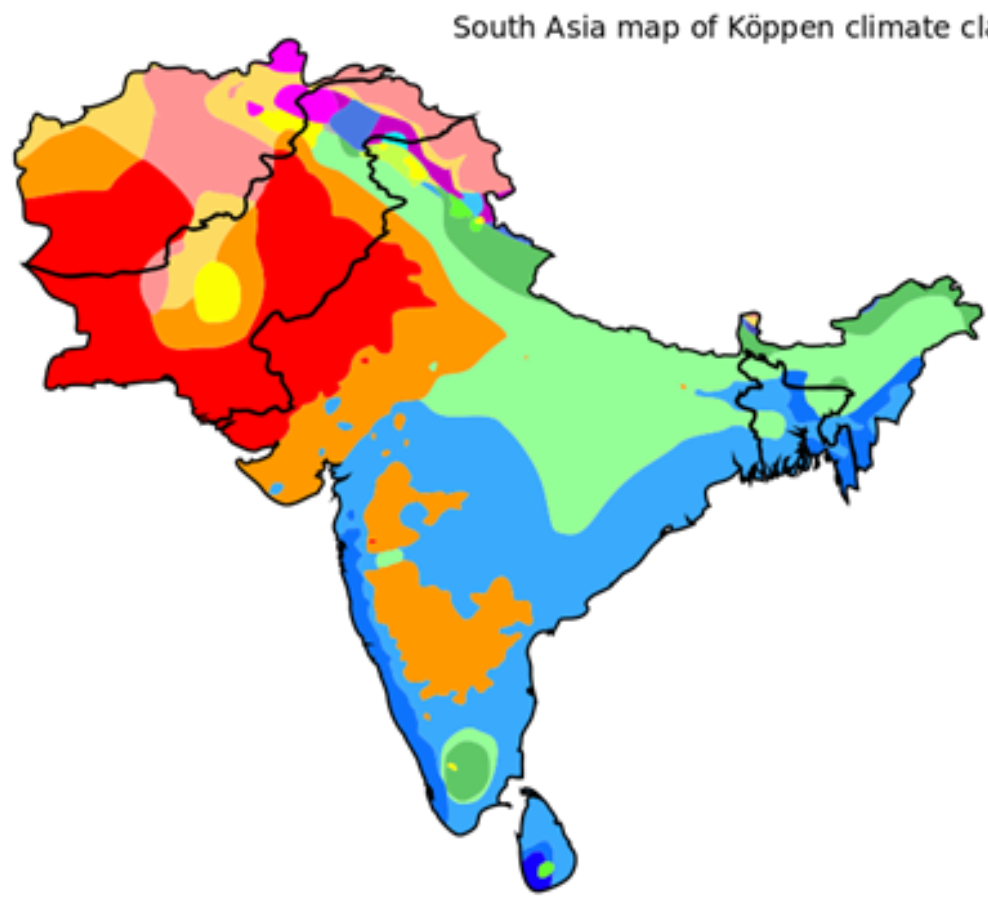

Figure 1A: Köppen Climate Classification of South Asia with equatorial rain forest climate (Af) depicted only in SW Sri Lanka in the whole of South Asia.

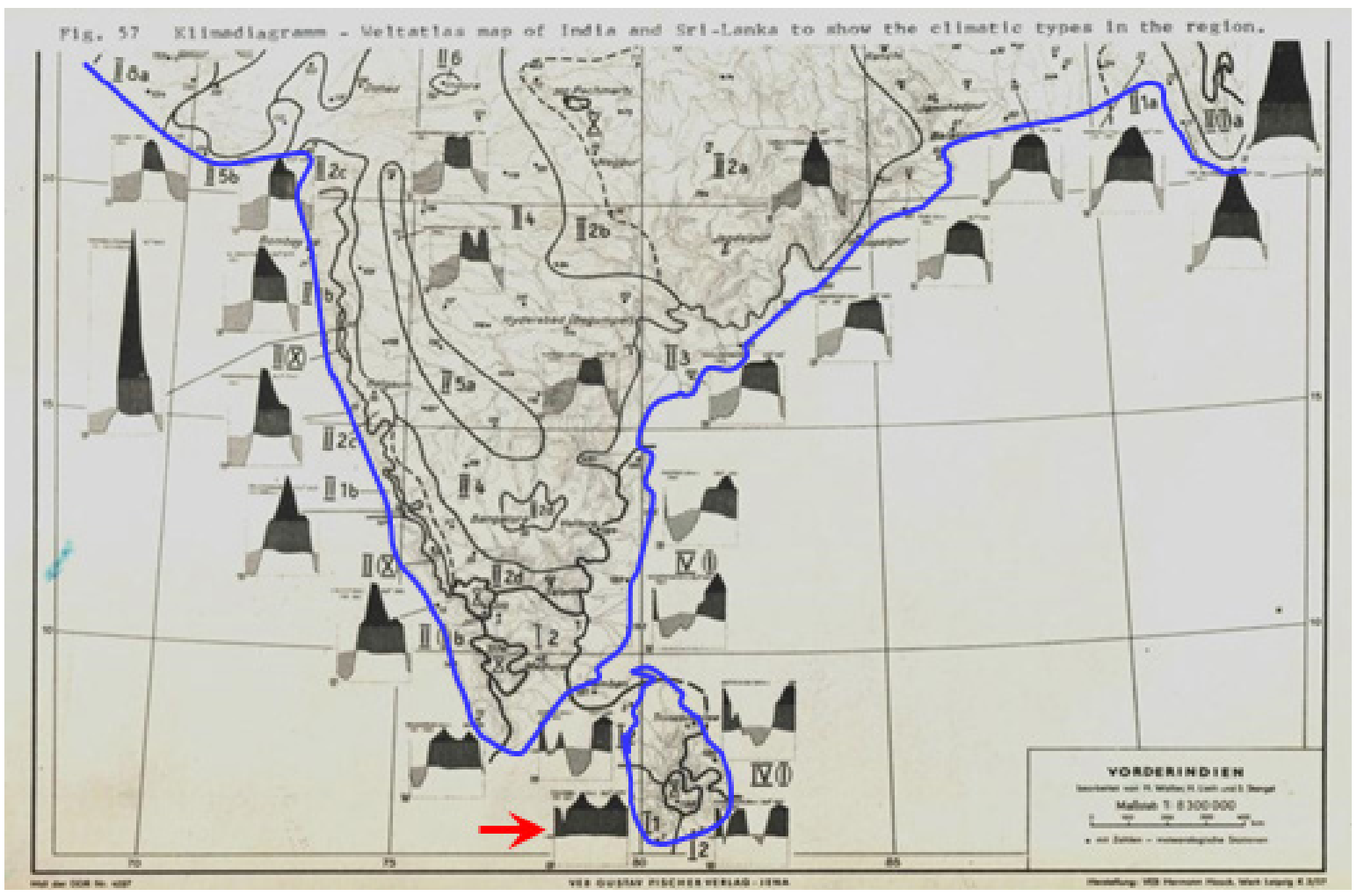

Figure 1B: Walter's climadiagram showing aseasonal perhumid climate (i.e. all monthly average $>100 \mathrm{~mm}$ indicated by a red arrow) surviving only in southwest Sri Lanka in the entire Indian subcontinent. 
filtering) with more regional evolutionary processes (e.g. trait evolution, habitat specialization, and speciation) is of fundamental importance in modern phylogenetic approach in revealing historical biogeographic patterns. In addition, phylogenetic beta diversity (phylobetadiversity) which measures how phylogenetic relatedness changes across space provides an evolutionary approach to examine how community assembly and the associated traits of species in a community change in relation to both spatial and environmental gradients (Chave et al., 2007; Graham and Fine, 2008). Consequently, when phylobetadiversity is considered together with the traditional measures of beta diversity, environmental gradient analysis or ecological niche modelling can yield significant and novel insights into the mechanisms underlying existing patterns of biological diversity (Graham and Fine, 2008).

In this respect, the Sri Lanka - Western Ghats Biodiversity hotspot offers an excellent platform to examine community ecology and phylogenetics incorporating large scale biogeographic patterns of major clades of both plants and animals (Ashton 2014; Meegaskumbura et al., 2002).

The ecologically relevant Köppen climate classification identifies SW Sri Lanka as the only region having a 'fully humid equatorial rainforest' (Af) in the whole of contemporary South Asia (Kottek et al,. 2006; Roubel and Kottek, 2010; Chen and Chen, 2013). The equivalent wettest type of climate in the Thornthwaite climate classification is the perhumid climate which too, is found nowhere else in the whole of South Asia but only in SW Sri Lanka (Thornthwaite, 1948, Feddema, 2005) (Figure 1 ). The perhumid climate is defined by the absence of predictable annual periods of water stress, with mean monthly rainfall in excess of expected evapotranspiration throughout the year (Ashton, 2014). The nearest lowland regions with similar perhumid climate are found in the Malesian biogeographic region to the east and in the Neotropics (in a small area of the upper Amazon near the Andean foothills, the Choco region of the northwestern coast of South America, and also in the narrow coastal regions of Central America facing the Caribbean) to the west. Such a perhumid climate does not exist in present day lowland Africa, but prevails at higher altitudes in Central Africa (Ashton, 2014; Feddema, 2005). These perhumid climates in both Asian and Neotropical lowlands support the most species-rich terrestrial ecosystems of the world their tropical rain forests.

\section{SW SRI LANKA AS A FLORISTIC REFUGIUM}

Recent phylogeographic studies have shown that tropical rain forest refugia may have played a critical role in conserving comparatively old lineages, particularly during unfavourable climatic periods, and contributed to the present day species diversity through either gradual accumulation of ancestral lineages through time (Museum model) or through ancient or recent rapid radiations (Ancient and Recent Cradle models) (Couvreur et al., 2011). These hypothetical processes, examined using phylogenetic reconstructions combined with fossil-calibrated molecular dating techniques, help to advance our understanding of the historical assembly, by revealing alternative lineage accumulation through time. It has been reported that Southern Western Ghats have served as such a refuge during Deccan volcanism for scolopendrid centipede genus Digitipes, a taxon confined to wet evergreen forests and the taxa commenced their range expansion to the northern areas of the Western Ghats in the post-volcanic periods in the Paleocene (Joshi and Karanth, 2013).

The existence of such refugia could play an important role in accumulating and preserving vital signatures of ancient lineages which have contributed to present day species diversity through range shifts/expansions via episodic corridors (Antonelli et al., 2010; Ashton, 2014; Prasad et al., 2009). Consequently, such refugial hotspots of biological diversity are indeed among the best laboratories for identification of and analysis for conservation through prioritized phylogeographic research (Couvreur et al., 2008, Joshi and Karanth, 2013).

Perhumid SW Sri Lanka is one such refugium on account of its extraordinary endemism, and species richness unique for South Asia reflecting its history with unusually pristine clarity (Ashton, 2014). The ever-wet equatorial climate that prevails in the Malesian archipelago from Sumatra to New Guinea in Papuasia survives today in South Asia only in SW Sri Lanka. Added to that, it manifests an extra-ordinary level of local endemism, especially among its mountain ranges compared with those of similar stature in the Far East, thereby again reflecting a truly ancient biological heritage (Gunatilleke and Ashton, 1987; Ashton, 2014).

South-west Sri Lanka receives its annual rainfall from both the South-western and North-eastern monsoons, along with orographic inter-monsoonal rains during the rest of the year. A latitudinal gradient of climate resulting in everwet to increasingly seasonal rainfall regimes exists from SW Sri Lanka through to the Western Ghats of South India (Ashton, 2014; Joshi and Karnath, 2013). This gradient correlates with a gradient in species richness at regional and landscape scales, and community species diversity, which declines northwards (Davidar et al., 2007). With the recognition of South-western Sri Lanka together with the Western Ghats as one of the 34 global biodiversity hotspots, a number of studies have focused on how such high levels of species richness might be maintained through time and space (Myres et al., 2000; Ashton and Gunatilleke, 1987; Gunatilleke and Ashton, 1987; Gunatilleke et al., 2006). However, relatively little is known about the evolutionary processes that have led to the generation of these hyper-rich ecosystems and their phylogenetic diversity. This extraordinary diversity can best be explained by understanding their evolutionary history in relation to the land and climatic history and the accompanying biogeographic processes (Datta-Roy and Karanth, 2009; Prasad et al., 2009).

An ever-wet climate may have flourished on the Indian Plate, retreating south and persisting in refugia during climatic vicissitudes of the Neogene, notwithstanding several periods of ice-age aridity (such as global cooling during the Eocene/Oligocene boundary 37-33 Ma) and later in the Quaternary (Raven and Axelrod, 1974; Datta- 
Roy and Karanth, 2009; Prasad et al., 2009; Joshi and Karnath, 2013). Raven and Axelrod, (1974) report how these latitudinal and climatic changes affected India during the Late Cretaceous and Tertiary, as the plate travelled from Gondwana and then collided with Asia. During this period widespread extinctions in India's biota occurred. This makes it difficult to find clear-cut evidence for 'outof-India' dispersal. However, with the palynological evidence (Morley, 2000; Prasad et al., 2009) and findings from phylogenetic reconstruction studies, a far greater role for an 'Out of India' hypothesis for migration of plant taxa from Indian Gondwana to Asia is emerging (Ashton and Gunatilleke, 1987; Ashton, 2014; Conti et al., 2002; Eriksson et al., 2004; Datta-Roy and Karanth, 2009). South West Sri Lanka where an ever-wet climate still prevails represents a potential refuge for hyper-rich biota of perhumid climates and consequently, a unique phylogeographic oasis in an otherwise seasonal region in South Asia.

The SW Sri Lankan refuge therefore represents the survival of South Asian belt of perhumid equatorial climate and associated flora that, as the Indian Noah's Ark shifted northwards, providing an early opportunity for a second, post-African, migration eastwards to a floristically impoverished Malesia over a Bay of Bengal expanding through pressure of the Indian plate edge against the Southeast Asian (Figure 2 and see below). A seasonal tropical land bridge later resulted from the collision between India and southern Laurasia, which resulted in floristic mixing of both floras adapted to the prevailing climate (Ashton, 2014).

\section{TECTONIC AND PLANT GEOGRAPHIC HISTORY OF THE INDIAN PLATE}

The South Asian subcontinent south of the Himalayas which is geologically referred to as 'India Plate' (including the Greater India basin that refers to the part of the Indian plate that has been subducted underneath Tibet since the onset of Cenozoic continental collision) originated on the northern coast of Gondwana as a result of splitting of the Gondwana supercontinent along with Australia and Madagascar from Africa and South America during the Jurassic period (Raven and Axelrod, 1974; Morley, 2000; Ali and Aitchison, 2008). At the time of the rift of the IndoMadagascar-Seychelles bloc from Gondwana, it bore a flora closely similar to that of contemporaneous Australia, with southern conifers and ferns (Morley, 2000). Subsequently, this block broke off from Australia sometime during the upper Jurassic period (150 Ma) probably in a warm temperate climate before the origin of modern flowering plant families which occurred in lower Cretaceous (135 -130 Ma) (Briggs, 2003, Chatterjee and Scotese, 1999, Kumar et al., 2007, Morley, 2000). The tectonic drift of the India plate north-eastwards commenced around 100 $\mathrm{Ma}$, first through seasonal tropical climates, then equatorial and at least partially perhumid climate while moving close to the African plate, before re-entering seasonal latitudes when it finally collided with the Asian plate in the middle Eocene (Morley 2000; van Hinsbergen et al., 2012; Ashton, 2014). Ali and Aitchison (2008) proposed the existence of a palaeogeographic connection between Madagascar and India in the late Cretaceous (85-65 Ma) via the SeychellesMascarene Plateau, which was exposed due to the sea-floor elevation; this connection was extended into the Palaeocene due to the development of volcanic islands associated with Réunion on mid-ocean ridges.

During the north-eastward tectonic drift of the India Plate through different climatic belts between Cenomanian and Campanian ages (100-83 Ma), it received diverse Upper Cretaceous elements of the African tropical flora replacing temperate elements of the eastern Gondwanan (austral) gymnosperm flora. These tropical African angiosperms were presumably already well adapted to

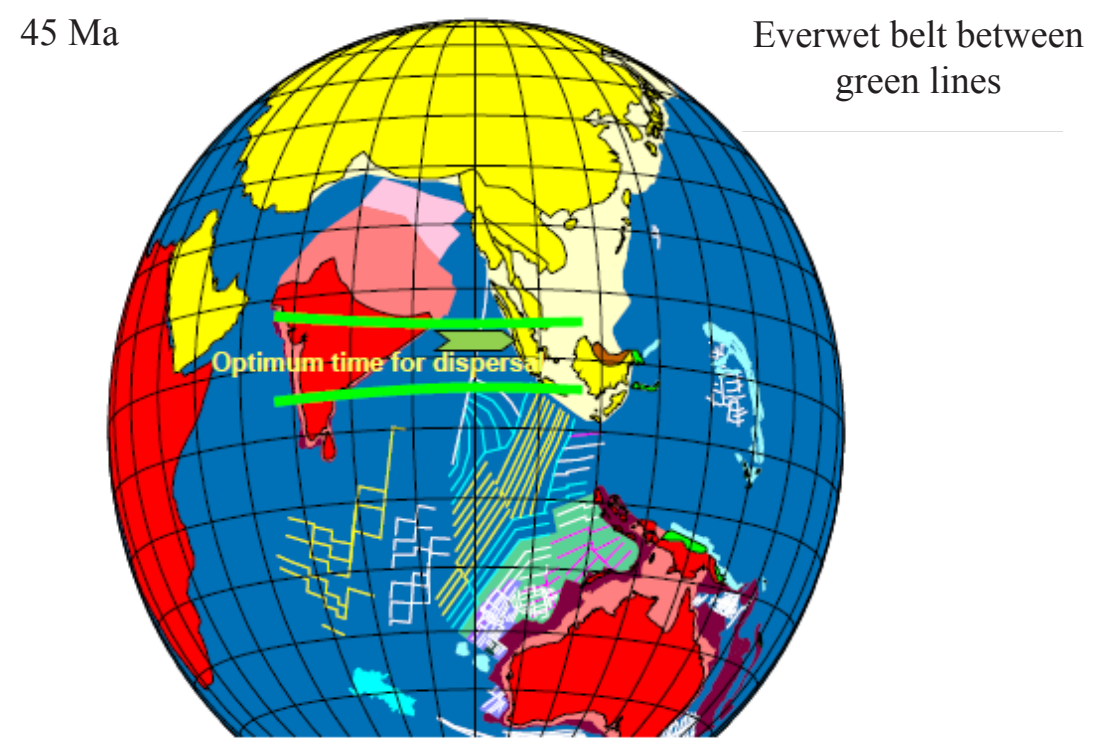

Figure 2 : Location of Indian Plate in the equatorial belt at around $45 \mathrm{Ma}$ providing the first and the last corridor of equatorial perhumid climate in this region and the only opportunity for migration of taxa confined to equatorial perhumid climate from India Plate to SE Asia (Adapted from Hall, 2009 and van Hinsbergen et al. 2012). 
seasonal tropical and perhumid equatorial climates of the African Plate (Morley, 2000). However, as India separated from Africa and drifted northwards, out of wet equatorial climates during the Maastrichtian/Paleocene (70-58 Ma), dispersals from Africa declined and many new endemic lineages would have evolved (Morley, 2000, Klaus et al., 2016). According to fossil and palynological records, by the close of the Cretaceous, India bore a rich, rapidly diversifying, megathermal angiosperm flora, contrary to the earlier suggestion by Raven and Axelrod (1974) that India was left with a rather generalized flora (Morley, 2000, Klaus et al., 2016). The widespread representation of megathermal groups possessing large arillate seeds, such as Malvaceae subtribe Durioneae strongly indicate that multistoried rain forests became well developed on the Indian Plate during the late Cretaceous as it rafted across the lower northern paleolatitudes (Morley, 2000).

During this time before the collision with Asia, the Indian Plate bore a flora with three distinct components:

i. An ancient, autochthonous Gondwanic component, carried from Gondwana, and consisting principally of warm temperate gymnosperms and pteridophytes, possibly with a few angiosperms and probably increasingly restricted to montane habitats,

ii. an allochthonous component arriving by islandhopping from Africa, consisting of megathermal angiosperm elements, and

iii. a diverse endemic component which evolved as India drifted across many climatic zones (Morley, 2000).

The survival of genera known exclusively from the Mixed Dipterocarp Forests and perhumid climates in both Sri Lanka and Malesia provide evidence for the existence of a migration route between them during early Eocene (Figure 2) (Ashton, 2014). Fossil evidence infers that a substantial proportion of the Asian lowland rainforest flora arrived principally via the Indian Gondwana route (Morley, 2000; Conti et al., 2002; Ashton, 2014, Klaus et al., 2016). Studies using strontium and stable carbon isotopes, microfossil biostratigraphy, and mammal fossils from an Early Eocene marginal marine sequence (Cambay Shale) at the Vastan Lignite Mine of western India indicate that terrestrial faunal exchanges, and therefore continental collision, between Asia and the Indian subcontinent took place before 53.7 Ma. This age coincides with the second Eocene Thermal Maximum (ETM2), a short-lived warming episode that followed the Paleocene-Eocene Thermal Maximum (PETM) ca. 55.5 Ma (Clementz et al., 2010). But the main collision between the Indian and Asian plates occurred ca. 35 Ma (Aitchison et al., 2007), at $>27^{\circ} \mathrm{N}$ therefore in a seasonal though likely tropical wet climate albeit before the rise of the Tibetan Plateau and, much later, Himalaya. The earlier opportunities for migration of perhumid climate taxa must have been instead for a second, post-African, oversea migration across the expanding Bay of Bengal (Figure 2) (Klaus et al., 2016). Klaus et al. (2016) report that the increased 'Maximal number of Dispersal Events' (MDEs) from India towards mainland Asia, coupled with stagnant MDE values for the opposite dispersal direction, suggests an aggressive Indian biota, which had become well-adapted to warm and wet early Eocene equatorial climates, extensively replacing the SE Asian biotas

As the Indian plate continued to move northwards away from the equator after the land connection was established, it moved out of the ever-wet tropical climatic belt in to increasingly cooler and more seasonal climates and the perhumid equatorial belt was transferred ever southwards. The wet seasonal migration land corridor from South Asia flourished during the second Cenozoic global warm period, throughout the Miocene but persisting intermittently until the present (Ashton, 2014). Many taxa unique and endemic to the Indian Plate appear to have been eliminated by massive extinctions of the majority of India's rain forests caused by a) rapid latitudinal change in India's position during the Early Cretaceous until its collision with Eurasia some $35 \mathrm{Ma}$ and b) the Neogene climate changes and associated volcanic activities (Ali \& Aitchison, 2008; Morley, 2000). During the Late Miocene, shifts towards more seasonal climates led to the disappearance of rain forests across much of India, restricting them to SW regions of India and Sri Lanka (Morley, 2000, Couvreur et al., 2011; Joshi and Karanth, 2013; Prasad et al., 2009). During these inter-pluvial dry periods, both South Indian and Sri Lankan rainforests must have suffered massive extinction, having retreated to refugia in the steep inner valleys of the mountains (Datta-Roy and Karanth, 2009; Prasad et al., 2009; Joshi and Karanth, 2013).

Consequently, very little evidence of this rich history of lineages of Early Tertiary vegetation is revealed from the examination of the present day flora of the Indian subcontinent with the exception of small refugia in SW Sri Lanka and the Western Ghats. These continue to provide vital biogeographic information of the role of the Indian Plate in the evolution of Southeast Asian and Far-Eastern biota (Ashton and Gunatilleke, 1987; Morley, 2000; Karanth, 2006, 2015; Prasad et al., 2009; Ashton, 2014).

\section{THE SRI LANKAN FLORA REFLECTS ITS MIGRATION HISTORY}

Palynological evidence reveals that an array of pollen types of taxa still extant in the rainforests of South Asia has been recorded from the Eocene flora of the Indian Plate (Morley, 2000). These include the distinctive Durio-type of the Malvacean tribe Durioneae (now endemic to tropical Asia but formerly also in Africa). They also include one genus Cullenia (now included in Durio), endemic to South Asia and four genera in the Far East. Furthermore, there is palynological evidence that Arecoid palms, Garcinia and Mesua of Clusiaceae and Callophyllaceae respectively, some Meliaceae and Euphorbiaceae, and the genera Dipterocarpus and Shorea of Dipterocarpaceae which are still extant in tropical rain forests of South Asia had been present in Upper Paleocene and lower Eocene pollen floras of the Indian Plate (Ashton, 2014; Dutta et al., 2011; Prasad et al., 2009). 
Resin chemistry and wood anatomy of 50-52 millionyear old amber specimens of Cambay shale outcrops from Gujarat, Western India provide definitive evidence of dammar-type resins and fossil wood of Dipterocarpaceae (Rust et al., 2010). They further report that the Eocene Cambay Shale amber deposits with their diverse arthropod inclusions were formed in broad-leaved tropical forest ecosystems in an ever-wet paleo-environment at the paleoequator: ever-wet because it provided the conditions for fossilization of pollen and wood in mire and peat that cannot form at tropical temperatures in seasonal climates. This provides one of the earliest unequivocal Asian records of a uniquely diverse and early biota of a modern type of dipterocarp primary forests that dominate south-east Asia today (Rust et al., 2010).

While relatively little fossil evidence from angiosperms is available for dispersal from India into Asia, phylogenetic reconstructions and molecular dating estimates have provided corroborative evidence in support of 'out of India' hypothesis as inferred from plant families such as Crypteroniaceae (Conti et al., 2002; Rutschmann et al., 2004), Dipterocarpaceae (Morley, 2003; Dayanandan et al., 1999; Gamage et al., 2006, Dutta et al., 2011; Ashton, 2014), Melastomataceae (Morley and Dick, 2003) and from animal taxa e.g. frogs (Bossuyt and Milinkovitch, 2001), acrodont lizards (Macey et al., 2000) and ratite birds (Cooper et al., 2001).

The Dipterocarpaceae subfamily Dipterocarpoideae with an extant distribution in Seychelles and Asia with 13 genera and about 475 species are clearly shown to be of Indian Gondwana origin and subsequent migration to and diversification in South-east Asia (Dayanandan et al., 1999). There is well-correlated molecular and morphological evidence for their diversification implying that the taxa of wet and perhumid climates confined to South Asia are basal in the subfamily and that the Neotropical and African taxa of the subfamilies Pakaramoideae and Monotoideae respectively, are in turn basal to the Asian taxa of Dipterocarpoideae (Gamage et al., 2006). Among the derived dipterocarpoids now confined to the perhumid Far East are the several red and the yellow Meranti (Richetioides) sections of Shorea, and Hopea (sect. Dryobalanoides and sect. Hopea subsect. Pierrea). However, there are a number of species in perhumid southwest Sri Lanka with sister species in wet seasonal Far East, implying that they may have migrated by a more recent wet, but seasonal route (Ashton, 2014, Table 1). Couvreur et al., (2011) present a comparative approach of comparing several species-level dated molecular phylogenies of genera in South-east Asia and South Asia in establishing migratory routes of different taxa from Gondwana to Asia during different geological periods. They predict that under a boreotropical geodispersal hypothesis most extant South Asian species are nested within South-east Asian ones, whereas South-east Asian species would be nested within South Asian lineages under an Indian rafting hypothesis. Such studies on South-west Sri Lankan and Western Ghats taxa would throw much light on the relative contributions of the two migratory routes. This approach must take account of the virtual absence of Australasian elements, currently concentrated in the Far Eastern equatorial montane forests, and those of warm temperate Far Eastern origin, notably Fagaceae, in the South Asian fossil record and contemporary flora (but see Heckenhauer et al., 2017).

As the Indian Gondwana plate moved towards Laurasia, perhumid refugial zones may have existed in the earlier, equatorial northern regions of the former as it moved northwards, but even these would have been replaced by seasonal wet tropical forests by the time of the collision. Taxa confined to perhumid climates such as Axinandra and Trichadenia could have survived in transit from east Africa at first, before migrating across the sea to the Far East, and simultaneously surviving in the Indian perhumid climatic

Table 1: Sister dipterocarp species in South and South-east Asia, and their forest formations (from Ashton 2014) MDF: Mixed Dipterocarp Forest, EDF: Evergreen Dipterocarp Forest, EF: Evergreen Forest.

\begin{tabular}{llll}
\hline \multicolumn{1}{c}{ South Asia } & \multicolumn{1}{c}{ South-east Asia } \\
\hline Name & Habitat & Name & Habitat \\
\hline Dipterocarpus hispidus & MDF & D. baudii & MDF, Southern seasonal EDF \\
D. zeylanicus & MDF & D. turbinatus & Semi-EDF \\
D. indicus & Southern seasonal EDF & D. turbinatus & Semi-EDF \\
& & & Upper dipterocarp forest \\
D. glandulosus & MDF & D. costatus & Southern seasonal EDF \\
Hopea brevipetiolaris & Semi-EF & Hopea reticulata & Northern seasonal EDF \\
H. ponga & Semi-EF & H. oblongifolia & Southern seasonal EDF \\
H. parviflora & Southern seasonal EDF & H. odorata & MDF, Southern seasonal EDF-Semi-EDF \\
Shorea dyeri & MDF & Shorea guiso & MDF, Southern seasonal EDF-Semi-EDF \\
S. stipularis & MDF & S.hypochra & MDF, Southern seasonal EDF-Semi-EDF \\
\hline
\end{tabular}



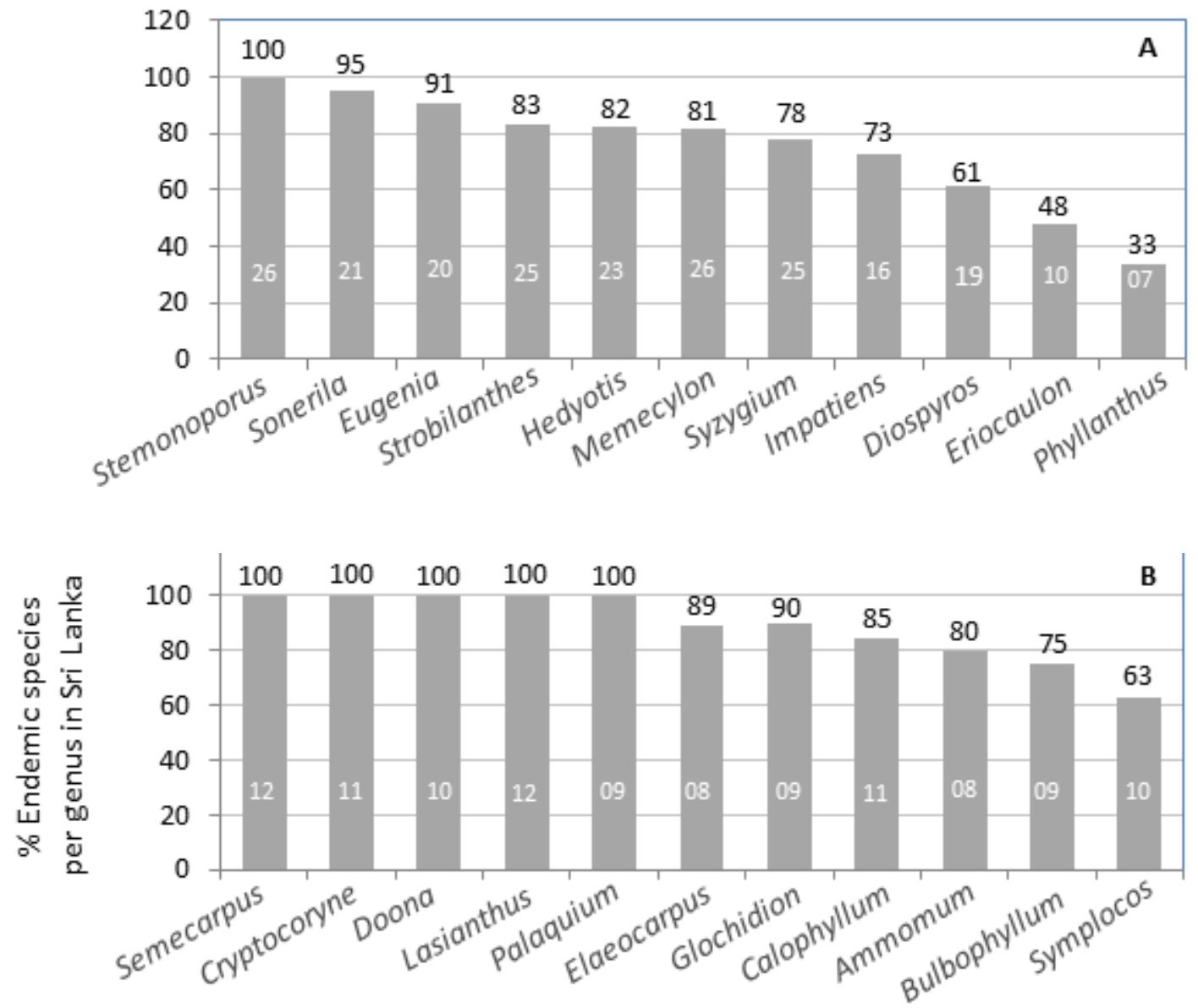

Figure 3: Speciose plant genera with a high percent of endemics in the Sri Lankan flora most of which are restricted to SW Sri Lanka. a) Genera with $>20$ species per genus and b) genera with $<20$ species per genus, recorded in the island. Numbers within bars indicate the number of endemic species in each genus.

belt as it was shifted southwards to its current Sri Lankan fastness. Axinandra (Crypteroniaceae), Trichadenia (Sterculiaceae), Cotylelobium (Dipterocarpaceae), Schumacheria (Dilleniaceae) and Humboldtia (Fabaceae) remain as survivors to the ever-wet climates of SW Sri Lanka and the Far East which are separated by $2000 \mathrm{~km}$ exhibiting a clear disjunct distribution (Ashton, 2014). Only one plant taxon at familial level failed to migrate eastwards from South Asia after this great collision which is Monimiaceae subfamily Hortonoideae, consisting of a single genus with 2-3 species endemic to SW Sri Lanka (Renner et al., 2010). However, there are several other supra-specific taxa similarly restricted: Stemonoporus, Vateria and Shorea section Doona (all of Dipterocarpaceae). These taxa must have survived in South Asian refugia during the subsequent widespread dry periods that separated Late Eocene and mid-Miocene global temperature maxima when wet albeit increasingly seasonal climates would have prevailed as India shifted northwards (Ashton and Gunatilleke, 1987; Ashton, 2014, Heckenhauer et al., 2017).

\section{ECOLOGICAL PHYTOGEOGRAPHY OF SRI LANKA}

Community ecological studies can contribute to increase our understanding of the causes of large-scale biogeographical patterns by studying local and individual-scale ecological patterns underpinning range limits of selected species from major clades (Wiens and Donoghue, 2004). There is an emerging trend in integrating community ecology (which investigates the nature of physical and biotic interactions, their origins and their ecological consequences) with phylogenetic relationships (trait evolution, habitat specialization, speciation) of organisms in understanding the origins and histories of species within a community, and offers hypotheses on the influence of historical and ecological factors in structuring communities (CavenderBares et al., 2009; Graham and Fine, 2008; Webb et al., 2002).

For its size $\left(65,610 \mathrm{~km}^{2}\right)$, Sri Lanka is the floristically richest area in the whole of South Asia with 1,363 genera and 3,154 species including a number of naturalized species. There are 14 endemic genera and 894 endemic species $(23.7 \%)$ in the angiosperm flora of Sri Lanka and about $90 \%$ are now restricted to its south-western perhumid quarter (Figure 3) (Wijesundera et al., 2012). Endemism among the tree communities of Mixed Dipterocarp Forest formation is over $80 \%$ in both the number of individuals and the basal area per ha but it is lower in the seasonal evergreen forests covering three quarters of the island (Gunatilleke and Ashton, 1987). The rainforest flora of South Asia shares about $95 \%$ of its tree genera with Far Eastern rainforests but less than a quarter of its species. This similarity in tree genera suggest the survival of genera 


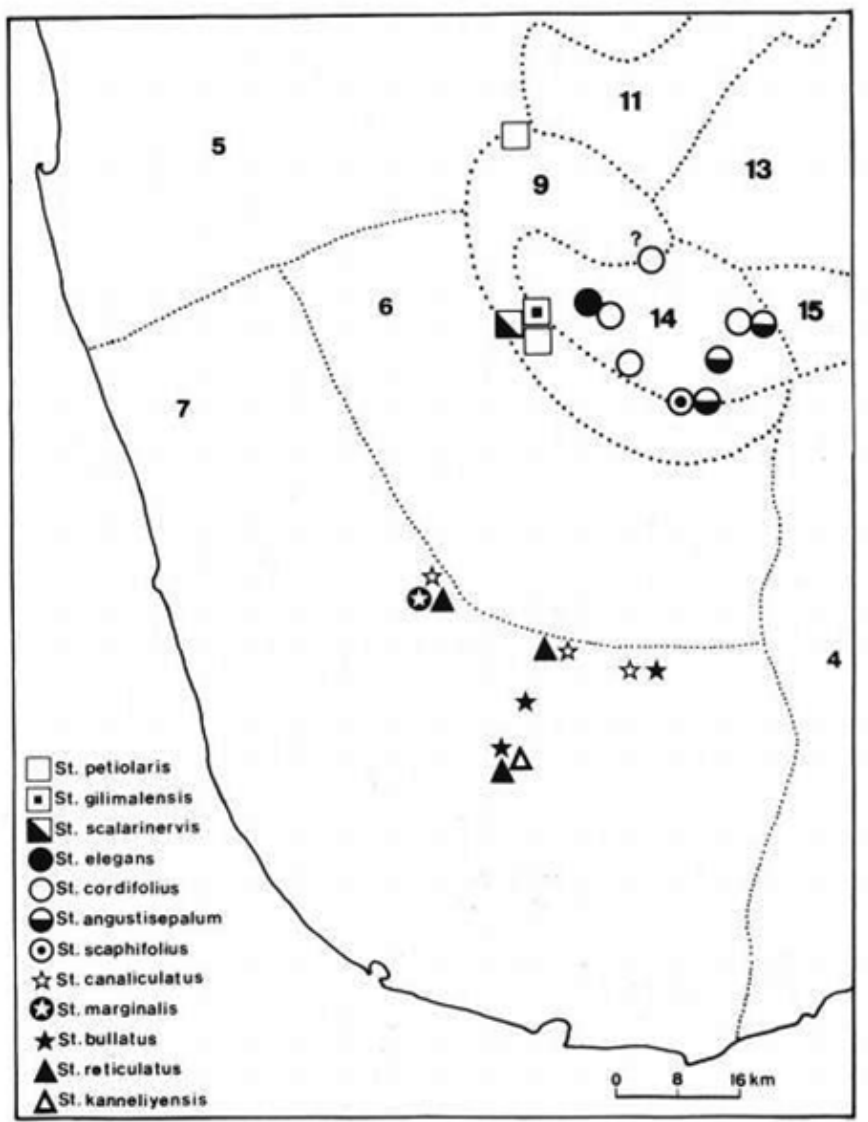

Figure 4: Restricted distribution of species of Stemonporus (Dipterocarpaceae) in SW Sri Lankan floristic regions (From Ashton and Gunatilleke, 1987).

known exclusively from Mixed Dipterocarp Forests and perhumid climates in both Sri Lanka and Malesia while re-emphasizing the existence of a migration path between them in the past (Ashton, 2014).

The perhumid SW Sri Lanka with a highly dissected terrain and several parallel ridges and valleys running SE-NW has favoured the evolution of species with restricted distribution. It is a major repository of exceptional floristic richness and tree species endemism with a number of highly speciose genera exhibiting range-restricted distribution of their endemic species (Figure 3). Of these, the endemic genus Stemonoporus (Dipterocarpaceae) with over 20 species, most of which are distributed in a restricted manner, both altitudinally and horizontally, within the lowland and lower montane forests in the SW Sri Lanka, show exceptional rate of diversification and habitat specialization (Figure 4) (Ashton and Gunatilleke, 1987; Greller et al., 1987; Kostermans, 1992; Ashton, 2014).

Relative to the size of the local flora overall, montane plant species endemism, particularly that of the herbaceous flora, is quite high in Sri Lanka (Figure 5). There are separate centres of endemism in the western Peak Wilderness, Knuckles, Horton Plains, and in the higher eastern Sinharaja mountains, with the Peak Sanctuary representing the greatest (Ashton and Gunatilleke, 1987). The pattern of tree species endemism in Sri Lanka markedly resembles that of frogs in speciose genera (Bossuyt et al., 2004; Meegaskumbura et al., 2002). The relatively high degree of local endemism in the upper montane forest flora in Sri
Lanka as compared with that of Sunda mountains of SE Asia is most likely due to their greater isolation in Sri Lanka as moist refuges during periods of severe drought, when the south-west monsoons abated in response to Pleistocene north temperate glacial periods (Ashton, 2014).

\section{COMMUNITY ECOLOGY AND HABITAT SPECIALIZATION IN RAIN FORESTS OF SRI LANKA}

Several community ecological studies in primary rainforests in Sri Lanka showed patterns of dominant species guilds characteristic of their habitat specificity. Floristic variation in mixed dipterocarp forest at two sites in the perhumid SW Sri Lanka (Kottawa in the southernmost coastal lowlands, and Kanneliya $30 \mathrm{~km}$ to the north and at $250 \mathrm{~m}$ altitude) was correlated with topography, and also with soil phosphorus, as revealed from ordination analysis (Gunatilleke and Ashton, 1987). While species' water economy seems to be the principal mediator of this species distribution, soil nutrients too, although present in relatively lower concentrations than in South East Asian study sites, appear to play a subordinate role in tree species distribution in SW Sri Lanka (Ashton, 2014). Likewise, floristic analysis of three hill forests along an elevational gradient from coastal lowlands $(300-668 \mathrm{~m})$ to South-central hinterland (670-910m) in SW Sri Lanka separated each of them in to broadly distinct floristic communities, which broadly correlate with floristic and structural altitudinal zonation recognised in the Far East (Whitmore, 1984, Ashton, 

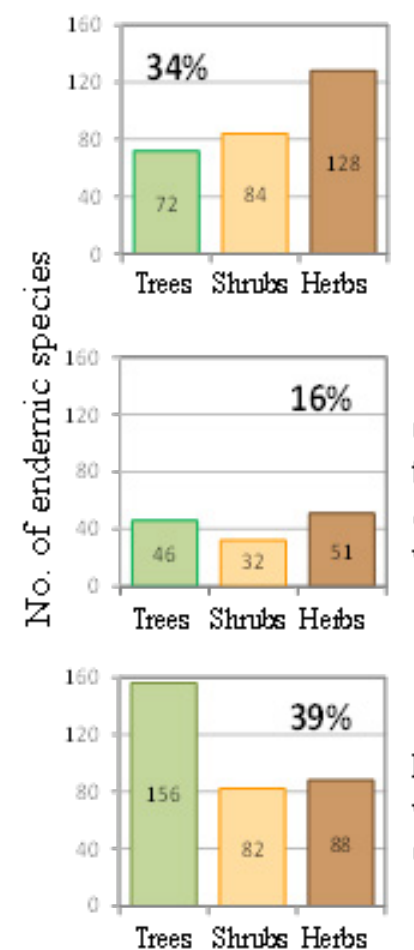

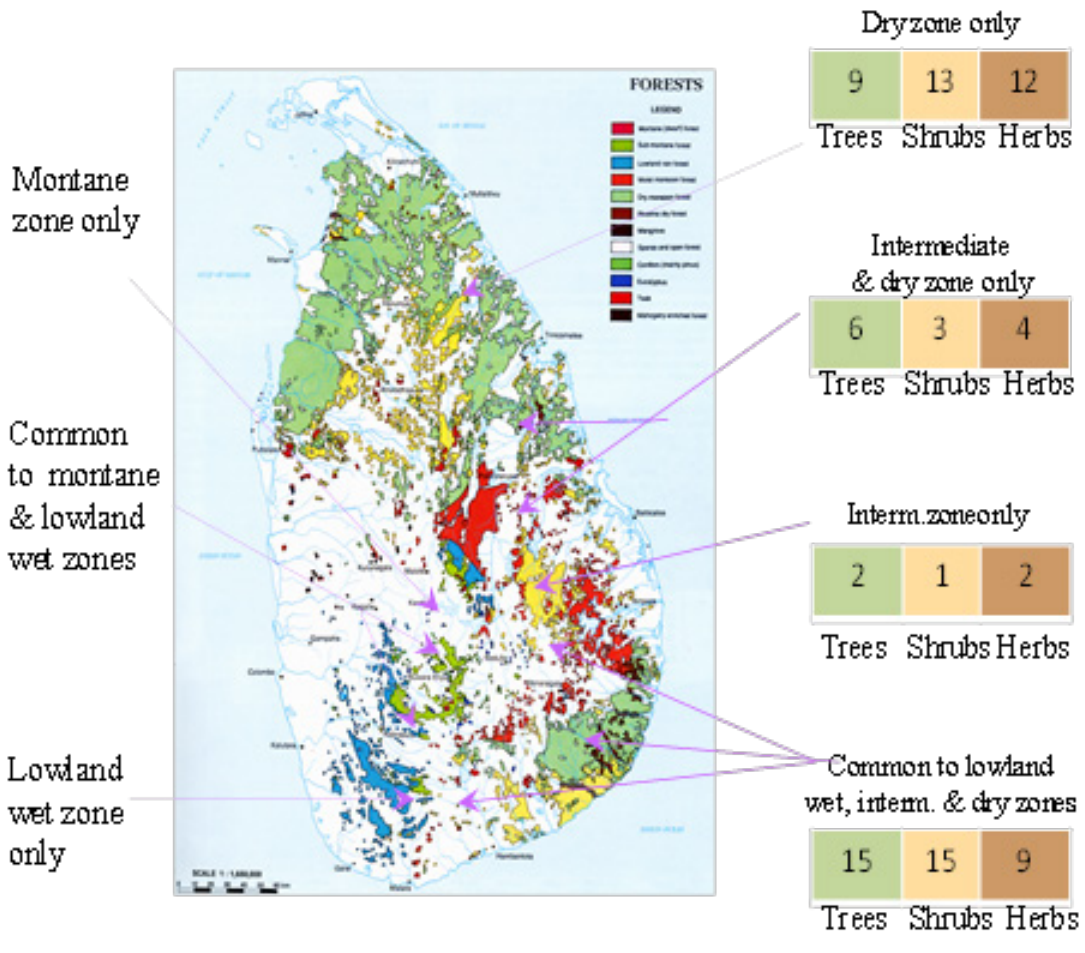

Dryzone orly

$13 \quad 12$

rees Shrubs Herbs \& dry zone only

Trees Shubs Herbs

Trees Shrubs Herbs

$89 \% \longleftarrow$ Proportions of enderric species distributed in different climatic zones $\rightarrow 11 \%$

Figure 5: Distribution of the number of endemic tree, shrub and herbaceous species among the different major climatic zones of Sri Lanka.

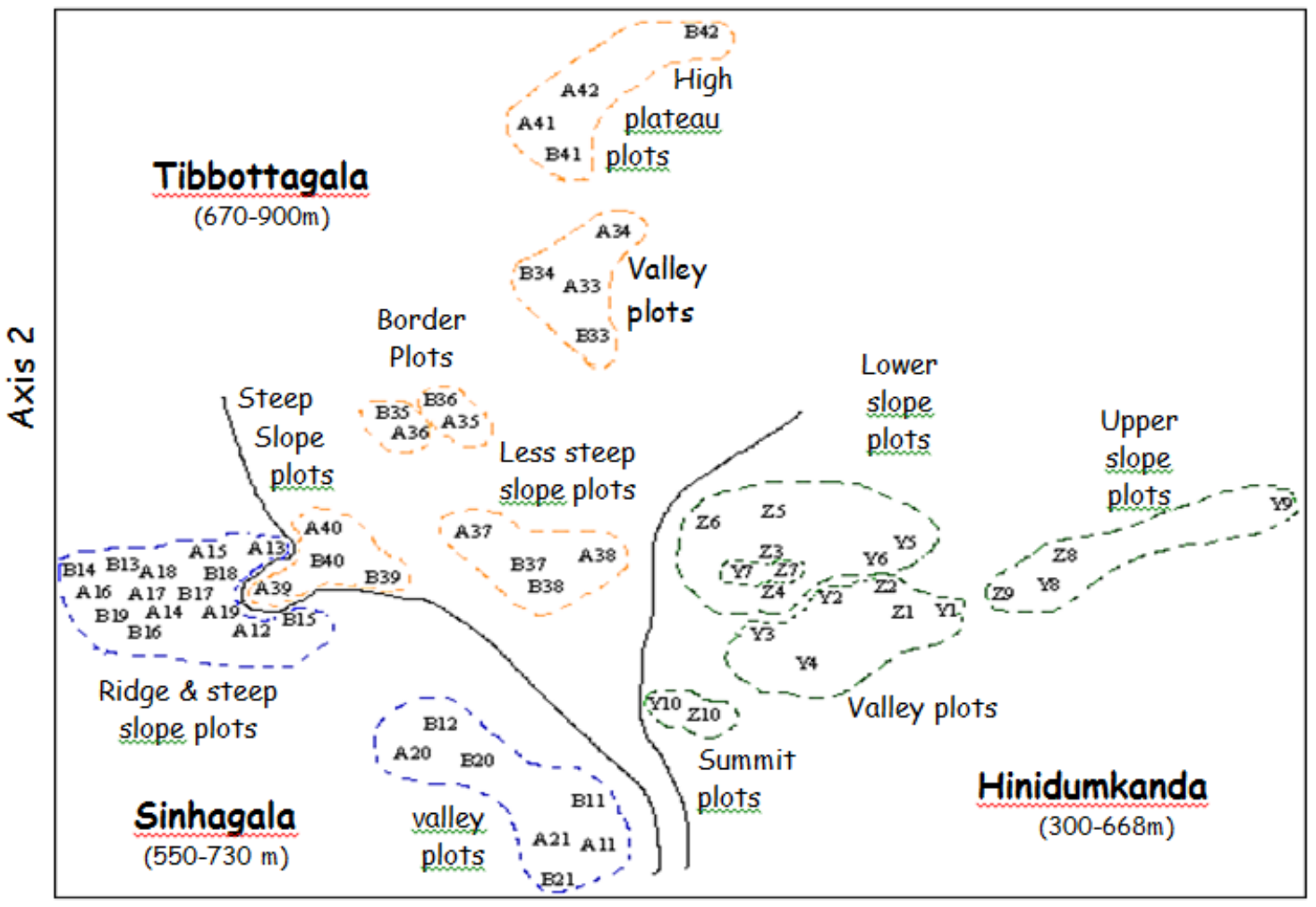

Axis 1

Figure 6: Ordination analyses of the distribution of plots sampled in three forests sites exhibiting landscape and local level floristic heterogeneity in hill forests at Hinidumkanda, Sinhagala and Thibbottagala respectively in southwest Sri Lanka (from Gunatilleke $e t$ al. 2005). 

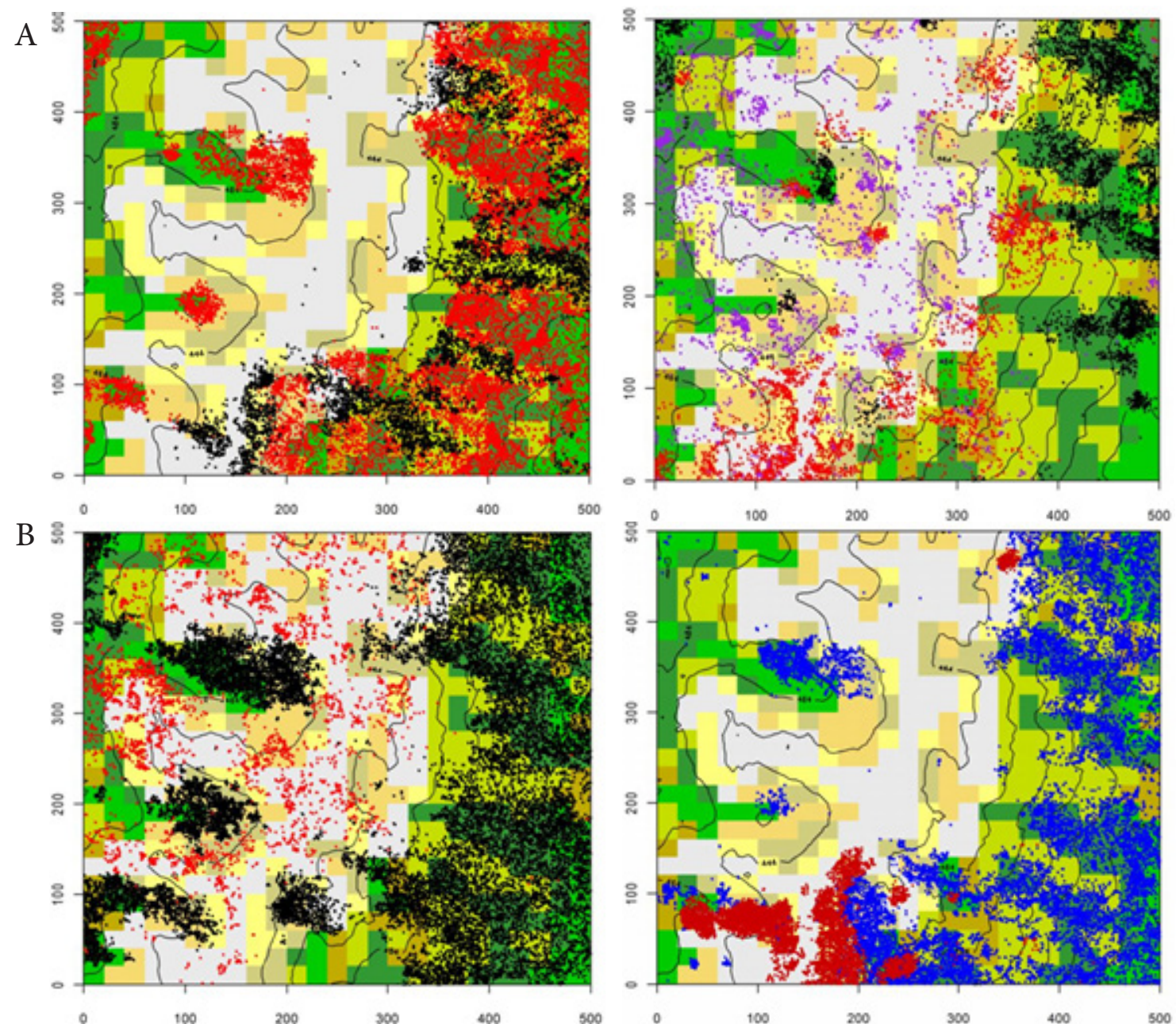

Figure 7: Spatial patterns of canopy (A) (Mesua spp. [left], Shorea spp. [right]) and, subcanopy and treelet (B) (Schumachaeria \& Humboldtia spp. [left] and Agrostistachys spp. [right]) in the 25 ha Forest Dyanamics Plot in the Sinharaja World Heritage Site, Sri Lanka exhibiting strong habitat associations among closely related and co-occuring species (from Gunatilleke et al., 2004).

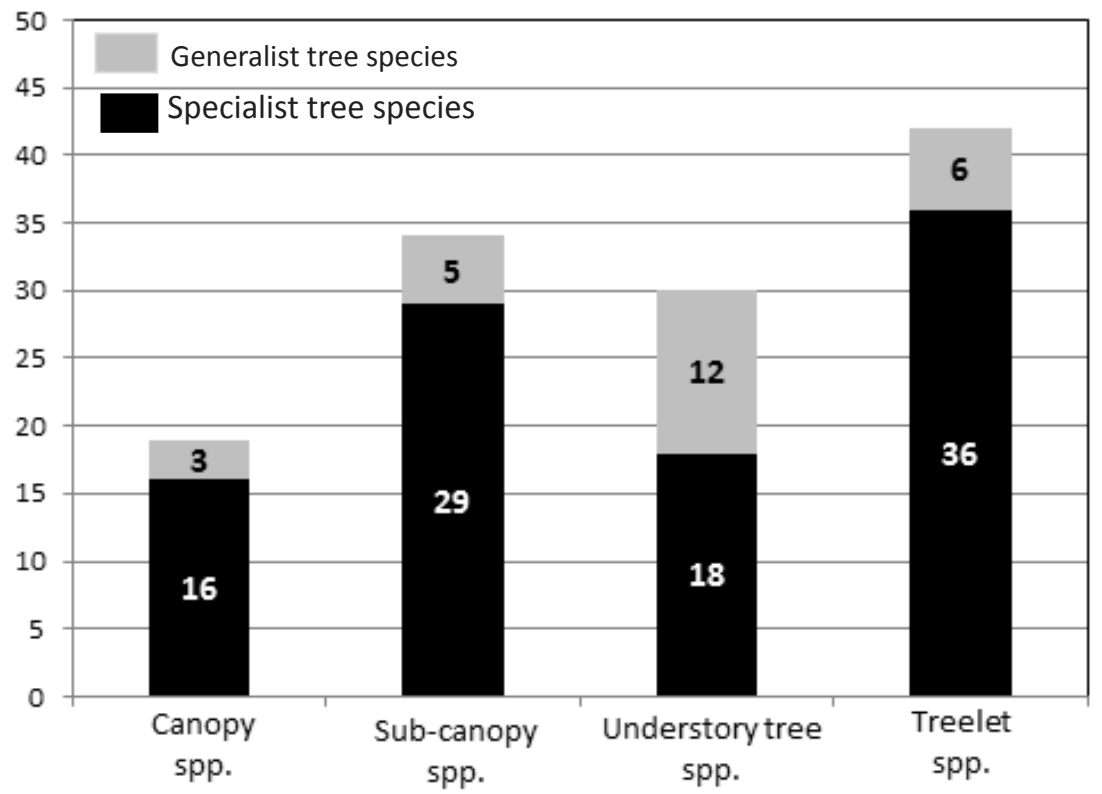

Life form groups among the forest trees

Figure 8: Habitat specialists among tree species in different lifeform categories in the 25 ha Forest Dyanamics Plot in Sinharaja World Heritage Site, Sri Lanka (from Gunatilleke et al. 2006). 
2014). They further revealed ecologically distinct species assemblages on the ridges, slopes and valleys within each forest type highlighting the presence of both landscapeand local habitat level floristic heterogeneity in the SW hill forests of Sri Lanka, which might reveal phylogenetic differences; but also separation of the sites themselves, and therefore the same forest type in different parts of the region, implying regional historical biogeographic floristic differentiation over recent, or possibly earlier time (Figure 6) (Gunatilleke et al., 2005). Striking is the floristic and dynamic similarity revealed between Sri Lankan and Far Eastern MDF sharing soils with similar water economy.

The local scale micro-habitat association and spatial patterns of plant species in the typically undulating 'ridgeslope-valley' landscape of Mixed Dipterocarp Forests of SW Sri Lanka was exemplified by the species distribution captured remarkably well in the Sinharaja 25-ha Forest Dynamics Plot (Gunatilleke et al., 2004; 2006). In this plot, $99(79 \%)$ of the 125 species with $\geq 100$ individuals each having $>1 \mathrm{~cm} \mathrm{dbh}$ are positively or negatively associated with one or more of the eight different habitats i.e. they were disproportionately over- or under-represented in most topographically defined habitats (Figure 7). These habitat specialists include a high proportion $(60-86 \%)$ of all life forms examined viz. canopy, sub-canopy, understorey tree, shrub and treelet species (Figure 8) (Gunatilleke et al., 2006). Habitat driven structuring was found to be stronger among adult and juvenile life stages than among recruits (Punchi-Manage et al., 2013). These strong associations between a majority of species distributions and habitats are consistent with ecophysiological, morphological and anatomical traits of the leading species examined using their seedlings under both natural and simulated environmental conditions (Ashton et al., 1995, Gunatilleke et al., 2006). These results confirm that fine-scale topographic and edaphic heterogeneity are important determinants of spatial patterning in Sinharaja 'ridge-slope-valley' landscape which is, in general, representative of the-forests of both perhumid SW Sri Lanka and the Far East. Trees in the valley are taller and have larger crowns than those on the ridges and upper slopes, where nutrients are more scarce (Ashton et al., 1993; Gunatilleke et al., 1996). Trees on ridge tops and upper slopes have more diffuse crowns, with smaller leaves as also seen in Far-eastern forests.

Patterns of species diversity in Sinharaja MDF forest plot and those of Lambir plots in North-western Borneo show similarities as well as differences. Sinharaja plot has relatively fewer tree species (205 species in its 25 ha) compared to those in Lambir (1179 species in its 52 ha) and Pasoh (781 species in its 25 ha) in SE Asia (Ashton, 2014). Soils on ridges are shallow at Sinharaja while at Lambir they are sandy and deep except to the south. However, the soils of the lower slopes in both Sinharaja and Lambir, are clay-loam with moderate nutrient level. In both Sinharaja and Lambir, mortality of emergent and canopy trees on rocky ridges is mostly of single trees dying standing creating smaller gaps. The relatively uniform canopy height along ridges in SW Sri Lankan rain forests (except in sheltered valleys where emergents are discernible) are an adaptation to prevailing SW monsoonal winds. The resulting reduced canopy heterogeneity in Sinharaja MDF forests is associated with rather higher sub-canopy diversity in relation to their respective canopy species diversity than in Far-eastern MDF. On slopes and valleys, the gaps are relatively larger due to shallow rooting in their clay soils, therefore multiple wind-throws and landslips, and points to greater turnover of stands. Valley plots in Sinharaja show higher species diversity (as measured by Fisher's alpha) than those of upper slope plots which show higher basal area. Consequently, these are among the most species diverse habitats in this steeply undulating landscape. In Lambir too, the basal area is highest on ridges and the diversity is relatively low (Gunatilleke et al., 2004, Ashton, 2014).

\section{CONCLUSIONS}

India-Seychelles-Madagascar plate broke off from the rest of East Gondwana plate before the origin of modern flowering plant families, probably in a warm temperate climate. It had moved north, first through seasonal tropical climates, then equatorial and at least partially perhumid, when it made initial contact with Laurasia in the Eocene from c. $57 \mathrm{Ma}$, before re-entering seasonal latitudes (Ali and Aitchison, 2008). There is emerging evidence that a limited perhumid dispersal corridor was opened up since this initial contact allowing biotic interchange between India and the mainland Asia having similar environmental conditions. The first appearance of angiosperms of Indian origin in Sundaland is reported at c. $49 \mathrm{Ma}$, with increased dispersal after 45Ma. Molecular phylogenetic evidence suggests that Asian dipterocarps originated in Gondwana and dispersed from India into Asia probably during a limited perhumid corridor existed between the Indian and Asian plate during the early/middle Eocene (Dutta et al., 2011). However, during the Late Miocene, changes towards more seasonal climates led to the disappearance of rain forests across much of India, restricting them to small refugia in the Southern-most parts of the Western Ghats of India and the perhumid SW Sri Lanka (Dayanandan et al., 1999; Morley, 2000; Gamage et al., 2006).

Niche separation along environmental gradients of elevation, topography and soils is seen to play as significant a role in community assembly in Sri Lanka as elsewhere (Gunatilleke et al., 2004, Silvertown, 2004). In addition, long-term canopy disturbance regimes appear to play a major role in maintaining species diversity in these forests (Ashton, 2014).

Perhumid SW Sri Lanka, a biological refugium within a global biodiversity hotspot, provides an excellent platform to address the questions on processes that determine community diversity and structure by incorporating historical biogeography into phylogenetic studies of community ecology. Comparative phylogenetic studies on taxa in Sri Lanka showing evidence of disjunct distribution in South and South-east Asia are a priority towards both improving our understanding on historical events that shaped their current distribution pattern, and driving regional therefore global commitment to conserve our natural heritage in a dangerously changing world. 
The questions that phylogenetic community ecology addresses are fundamental to understanding the nature of biological communities. With the increasing rate of global change - including land use change, habitat loss, species invasions, alterations in element cycling and global climate change - basic understanding of the causes and consequences of community structure has never been more important. Protecting our biological resources requires continued commitment to understanding how communities assemble and how they respond to forces of change.

With ever increasing habitat destruction worldwide, our understanding of how natural communities are assembled and the forces that influence their dynamics, diversity and ecosystem function would prove important in restoring degraded habitats and sustainably managing them (Webb et al., 2002; Ackerly, 2004; Cavender-Bares et al., 2009). Therefore, the study of community ecology and their phylogeny are of vital importance in conservation management of surviving unmodified ecosystems in a changing global climate accompanied by rapid loss of habitats due to deforestation and forest degradation. Further insights gained by applying phylogenetic approaches to explore the ecological and evolutionary factors that underlie the assembly of communities, will provide a basis for integrating local and national Sri Lankan policy and management into a regional and pan-Asian policy and political commitment.

\section{REFERENCES}

Ackerly, D.D. (2003). Community assembly, niche conservatism, and adaptive evolution in changing environments. Int. J. Plant Sci. 164: S165-S184.

Ackerly, D.D. (2004). Adaptation, niche conservatism, and convergence: comparative studies of leaf evolution in the California chaparral. American Naturalist 163: 654671.

Aitchison, J.C., Ali, J.C. and Davis, A.M. (2007). When and where did India and Asia collide? Journal of Geophysical research 112: B05423, 1-19. doi:10.1029/2006JB004706

Ali, J. R. and Aitchison, J. C. (2008). Gondwana to Asia: plate tectonics, paleogeography and the biological connectivity of the Indian subcontinent from the Middle Jurassic through latest Eocene (166-35 Ma). Earth-Sci. Rev. 88: 145-166.

Antonelli, A., Verola, C. F., Parisod, C. and Gustafsson, A. L. S. (2010). Climate cooling promoted the expansion and radiation of a threatened group of South American orchids (Epidendroideae: Laeliinae) Biological Journal of the Linnean Society 100: 597-607.

Ashton P.S. (2014). On the forests of tropical Asia: lest the memory fade. Royal Botanic Gardens, Kew and Arnold Arboretum of Harvard University, USA. 670 pp.

Ashton, P.M.S., Gunatilleke, C.V.S., and Gunatilleke, I.A.U.N. (1995). Seedling survival and growth of four Shorea species in a Sri Lankan rainforest. Journal of Tropical Ecology 1: 263-279.

Ashton P.S. and Gunatilleke C.V.S. (1987). New light on the plant geography of Ceylon. I. Historical plant geography. Journal of Biogeography 14: 249-285.

Baker, W.J. and Couvreur, T.L.P. (2013). Global biogeography and diversification of palms sheds light on the evolution of tropical lineages. I. Historical biogeography. Journal of Biogeography 40: 274-285.

Baker, W.J. and Couvreur, T.L.P. (2013). Global biogeography and diversification of palms sheds light on the evolution of tropical lineages. II. Diversification history and origin of regional assemblages. Journal of Biogeography, 40: 286-298.

Bossuyt, F., and Milinkovitch, M.C. (2001). Amphibians as indicators of early Tertiary "Out-of-India" dispersal of vertebrates: Science 292: 93-95.

DOI: $10.1126 /$ science. 1058875

Bossuyt, F., Meegaskumbura, M., Beenaerts, N., Gower, D.J. and Pethiyagoda, R. (2004). Local endemism within the Western Ghats-Sri Lanka biodiversity hotspot. Science 306 (5695): 479-481.

Briggs, J. C. (2000). The biogeographic and tectonic history of India. J. Biogeogr. 30: 381-388.

Cavender-Bares, J., Kitajima, K. and Bazzaz, F.A. (2004). Multiple trait associations in relation to habitat differentiation among 17 Floridian oak species. Ecol. Monogr. 74: 635-662.

Cavender Bare, J., Kozak, K.H.., Fine, P.V.A. and Kembel, S.W. (2009). The merging of community ecology and phylogenetic biology. Ecology Letters 12: 693-715. doi :10.1111/j.1461-0248.2009.01314

Chave, J., Chust, G. and Thebaud, C. (2007). The importance of phylogenetic structure in biodiversity studies. In: Scaling Biodiversity (eds. Storch, D., Marquet, P. and Brown, J.H.), Institute Editions, Santa Fe, pp. 151-167.

Chen, D. and Chen, H. W. (2013). Using Köppen classification to quantify climate variation and change: an example for 1901-2010. Environ. Dev. 6: 79-79.

Clementz, M. T., Bajpai, S., Ravikant, S. and Prasad, V. (2010). Early Eocene warming events and the timing of terrestrial faunal exchange between India and Asia. Geology 39(1): 15-18. http://geology.gsapubs.org/cgi/doi/10.1130/G31585....

Conti, E., Eriksson, T., Schonenberger, J., Sytsma, K.J. and Baum, D.A. (2002). Early Tertiary out-of-India dispersal of Crypteroniaceae: evidence from phylogeny and molecular dating. Evolution, 56: 1931-1942.

Cooper, A., Lalueza-Fox, C., Anderson, S., Rambaut, A., Austin, J. and Ward, R. (2001). Complete mitochondrial genome sequences of two extinct moas clarify ratite evolution; Nature (London) 409: 704-707.

Couvreur, T., Chatrou, L.W., Sosef, M.S.M. and Richardson, J.E. (2008). Molecular phylogenetics reveal multiple tertiary vicariance origins of the African rain forest trees. BMC Biology 6: 54. doi:10.1186/1741-7007-654.

Couvreur, T., Forest, F., and Baker, W.J. (2011). Origin and global diversification of tropical rain forests: inferences from a complete genus-level phylogeny of palms. $B M C$ Biology 9: 44. doi:10.1186/1741-7007-9-44

Dayanandan, S., Ashton, P. S., Williams, S. M. and Primack, R. B. (1999). Phylogeny of the tropical tree family Dipterocarpaceae based on nucleotide sequences of the chloroplast rbcL gene. Am. J. Bot. 86: 1182-1190. 
Datta-Roy, A. and Karanth, K. P. (2009). The 'Out-of-India' hypothesis: what do molecules suggest? J. Biosci. 34: 687-697.

Dutta, S., Tripathi, S.K.M., Mallick, S.M., Mathews, R.P., Greenwood, P.F., Rao, M.R. and Summons, R. 2011. Eocene out-of-India dispersal of Asian dipterocarps: Review of Palaeobotany and Palynology 166: 63-68.

Donoghoue, M.J. (2008). A phylogenetic perspective on the distribution of plant diversity. PNAS: 105 (Suppl. 1): 11549-11555.

Davidar, P., Rajagopal, P., Mohandass, D., Puyravud, J-P, Condit, R., Wright, S.J., and Leigh, Jr. E.G. (2007). The effect of climatic gradients, topographic variation and species traits on the beta diversity of rain forest trees. Global Ecology and Biogeography 16: 510-516.

Emerson, B.C. and Gillespie, R.G. (2008). Phylogenetic analysis of community assembly and structure over space and time. Trends Ecol. Evol. 23(11): 619-630. doi:10.1016/j.tree.2008.07.005.

Eriksson, M. E., Hints, O. Paxton, H. and Tonarová and P. Eriksson, M. E. (2004). Ordovician and Silurian polychaete diversity and biogeography. Geological Society, London, Memoirs 38: 265-272. doi:10.1144/ M38.18.

Feddema, J. J. (2005). A revised Thornthwaite-type global climate classification. Physical Geography 26 (6): 442446.

Gamage, D.T., de Silva, M.P., Inomata, N., Yamazaki, T. and Szmdt, A.E. (2006). Comprehensive molecular phylogeny of the sub-family Dipterocarpoideae (Dipterocarpaceae) based on chloroplasy DNA sequences. Genes Genet. Syst. 81: 1-12.

Graham, C.H. and Fine, P.V.A. (2008). Phylogenetic beta diversity: linking ecological and evolutionary processes across space in time. Ecology Letters 11(12): 1265 1375. doi:10.1111/j.1461-0248.2008.01256.x.

Greller, A. M., Gunatilleke, I.A.U.N., Jayasuriya, A.H.M., Gunatilleke, C.V.S., Balasubramaniam, S. and Dassanayake, M.D. (1987). Stemonoporus (Dipterocarpaceae) dominated montane forests in the Adam's Peak Wilderness, Sri Lanka. J. Trop. Ecol. 3(1): 243-253. httsps://doi.org/10.1017/ S0266467400002108.

Gunatilleke, C.V.S. and Ashton, P.S. (1987). New light on the plant geography of Ceylon. II. The ecological biogeography of the lowland endemic flora. Journal of Biogeography 14: 295-327.

Gunatilleke, C.V.S., Perera, G.A.D., Ashton, P.M.S., Ashton, P.S., and Gunatilleke I.A.U.N. (1996). Seedling growth of Shorea section Doona, (Dipterocarpaceae) in soils from topographically different sites of Sinharaja rain forest in Sri Lanka. In: The Ecology of Tropical Forest Tree Seedlings. Swaine, M. D. (ed.) UNESCO, Parthenon Press, Paris, pp. 245-266.

Gunatilleke, C.V.S., Gunatilleke, I.A.U.N., Ethugala, A.U.K., Weerasekara, N.S., Ashton, P.S., Ashton, P.M.S., and Wijesundara. S. (2004). Community ecology of a spatially explicit rain forest plot in Sinharaja, Sri Lanka. In: Forest Diversity and Dynamism: Results from the Global Network of Large-scale Demographic Plots. Losos, E., and E. Leigh (eds.). University of
Chicago Press, Chicago, pp. 235-256.

Gunatilleke, I.A.U.N., Gunatilleke, C.V.S. and Dilhan, M. (2005). Plant biogeography and conservation of the southwestern hill forests of Sri Lanka . The Raffles Bulletin of Zoology Supplement 12: 9-22.

Gunatilleke, C.V.S., Gunatilleke, I.A.U.N., Esufali, S., Harmes, K.E., Ashton, P.M.S., Burslem, D.F.R.P. and Ashton, P.S. (2006). Species-habitat associations in a Sri Lankan dipterocarp forest. Journal of Tropical Ecology 22: 343-356.

Hall, R., Van Hattum, M.W.A. and Spakman, W. (2008). Impact of India-Asia collision on SE Asia: the record in Borneo. Tectonophysics 451: 366-389.

Hall, R. (2009). Southeast Asia's changing palaeogeography. Blumea 54: 148-161.

Heckenhauer, J., Samuel, R., Barfuss, M.H., Turner, B., Tae-Soo, J., Temsch, E., Abu Salim, K., Attanayake A.M.A.S., Paun, O., Ashton, P. S. and Chase, M. W. (2017). Phylogenetic analyses of plastid DNA suggests a different interpretation of morphological evolution than those used as the basis for previous intuitive classifications of Dipterocarpaceae (Malvales). Botanical Journal of the Linnean Society, 185(1):1-26.

Hughes, C.E., Pennington, R. T. and Antonelli, A. (2013). Neotropical plant evolution: assembling the big picture. Botanical Journal of the Linnean Society, 171: 1-8.

Joshi, J. and Karanth, P. (2013). Did southern Western Ghats of peninsular India serve as refugia for its endemic biota during the Cretaceous volcanism? Ecology and Evolution 3(10): 3275-3282.

Karanth, K. P. (2006). Out-of-India Gondwanan origin of some tropical Asian biota. Current Science 90: 789-792.

Karanth, P. (2015). An island called India: phylogenetic patterns across multiple taxonomic groups reveal endemic radiations. Current Science 108 (10): 18471851.

Kostermans, A.J.G.H. (1992). A Handbook of the Dipterocarpaceae of Sri Lanka. Foundation for Useful Plants of Tropical Asia Volume III. Wildlife Heritage Trust of Sri Lanka, 244 pp.

Kottek, M. J., Grieser, C., Beck, B., Rudolf and Rubel, F. (2006). World map of the Köppen-Geiger climate classification updated. Meteorol. Z. 15: ro9-63.

Kumar, P., Yuan, X., Kumar, M. R., Kind, R., Li, X. and Chadha, R. K. (2007). The rapid drift of the Indian tectonic plate. Nature 449: 894-897.

Losos, J. B. (1996). Phylogenetic perspectives on community ecology. Ecology 77(5): 1344-1354.

Losos, J. B. (2008). Phylogenetic niche conservatism, phylogenetic signal and the relationship between phylogenetic relatedness and ecological similarity among species. Ecol. Lett. 11: 995-1003.

Macey, J. R., Schulte, J. A., Larson, A., Ananjeva, N., Wang, Y. Z., Pethiyagoda, R., Rastegar-Pouyani, N. and Papenfuss, T. J. (2000). Evaluating transtethys migration: an example using acrodont lizard phylogenetics; System. Biol. 49: 233-256.

Meegaskumbura, M., Bossuyt, F., Pethiyagoda, R., and Manamendra-Arachchi, K. (2002). Sri Lanka: an amphibian hot spot. Science 298 (5592): 379-379. 
Mittelbach, G. G., Schemske, D. W., Cornell, H. V., Allen, A. P., Brown, J. M., Bush, M. B., and Turelli, M. (2007). Evolution and the latitudinal diversity gradient: Speciation, extinction and biogeography. Ecology Letters 10(4): $\quad 315-331 . \quad$ DOI: $10.1111 /$ j.14610248.2007.01020.x

Morley, R. J. (2000). Origin and evolution of Tropical Rain Forests, Wiley, Chichester, 362 pp.

Morley, R.J., and Dick, C.W. (2003). Missing fossils, molecular clocks, and the origin of the Melastomataceae. American Journal of Botany 90: 1638-1644.

Myers, N. (2000). Biodiversity hotspots for conservation priorities. Nature 403: 853-858.

Prasad, V., Farooqui, A., Tripathi, S.K.M., Garg, R. and Thakur B. (2009). Evidence of Late Paleocene-Early Eocene equatorial rain forest refugia in southern Western Ghats, India: Jour. of Biosciences 34: 771-979.

Punchi-Manage, R., Getzin, S., Wiegand, T., Kanagaraj, R., Gunatilleke, C. V. Savitri, Gunatilleke, I. A. U. Nimal, Wiegand, K. and Huth, A. (2013). Effects of topography on structuring local species assemblages in a Sri Lankan mixed dipterocarp forest. Journal of Ecology 101: 149-160.

Raven, P.H. and Axelrod, D.I. (1974). Angiosperm biogeography and past continental movements. Annals of the Missouri Botanical Garden 61: 539-637.

Renner, S., Strijk, J.S., Strasberg, D. and Thebaud, C. (2010). Biogeography of the Monimiaceae (Laurales): a role for East Gondwana and long-distance dispersal, but not West Gondwana. Journal of Biogeography 37: 1227-1238.

Ricklefs, R.E. (1987). Community diversity: relative roles of local and regional processes. Science 235: 167-171.

Ricklefs, R.E. (2007). History and diversity: explorations at the intersection of ecology and evolution. Am. Nat. 170 Supplement 2: S56-S70. https://www.ncbi.nlm.nih. gov/pubmed/17874385.

Richardson, J.E., Chatrou, L.W., Mols, J.B., Erkens, R.H.J. and Pirie, M.D. (2004). Historical biogeography of two cosmopolitan families of flowering plants: Annonaceae and Rhamnaceae. Philosophical Transactions of the Royal Society of London, B. 359 (1450): 1495-1508. DOI: $10.1098 /$ rstb.2004.1537.

Rubel, F. and Kottek, M. (2010). Observed and projected climate shifts 1901-2100 depicted by world maps of the Köppen-Geiger climate classification. Meteorol. Z. 19:135-41.

Rutschmann, F., Erikson, T. Schonenberger J. and Conti, E. (2004). Did Crypteroniaceae disperse out of India? Molecular dating evidence from rbcL, ndhF, and $\mathrm{rp} / 16$ intron sequences. Int. J. Plant Sci. 165 (Suppl.4): pp. S69-S83.
Rust, J., Singh, H., Rana, R.S., McCann, T., Singh, L., Anderson, K., Sarkar, N., Nascimbene, P.C., Stebner, F., Thomas, J.C., Solórzan Kraemera, M., Williams, C.J., Engel, M.S., Sahni, A. and Grimaldi, D. 2010. Biogeographic and evolutionary implications of a diverse paleobiota in amber from the early Eocene of India: Proc. Nat. Acad. Sci. USA 107: 18360-18365. doi:10.1073/pnas.1007407107

Silvertown, J. McConway, K., Gowing, D., Dodd, M., Fay, M. F., Jeffrey A. J.and Dolphin, K. (2006). Absence of phylogenetic signal in the niche structure of meadow plant communities. Proc. R. Soc. B. 273: 39-44.

Swenson, N. G. and Enquist, B. J. (2007). Ecological and evolutionary determinants of a key plant functional trait: wood density and its community-wide variation across latitude and elevation. American Journal of Botany 91: 451-459

Thorntwaite, W. (1948). An Approach toward a Rational Classification of Climate Geographical Review 38 (1): 55-94.

van Hinsbergen D.J.J., Lippert, P. C., Dupont-Nivet, G., McQuarrieh, N., Doubrovinea, P. V., Spakmani, W. and Torsvika, T.H. (2012). Greater India Basin hypothesis and a two-stage Cenozoic collision between India and Asia. PNAS 109 (20): 7659-7664.

Webb, C.O., Ackerly, D.D., McPeek, M.A. and Donoghue , M.J. (2002). Phylogenies and community ecology. Annu. Rev. Ecol. Syst. 33: 475-505.

Wiens, J.J. (2012). Why biogeography matters ?: historical biogeography vs. phylogeography and commun ity phylogenetics for inferring ecological and evolutionary processes. Frontiers of Biogeography 4(3): 128-135.

Wiens, J.J. and Donoghue, M.J. (2004). Historical biogeography, ecology, and species richness. Trends in Ecology and Evolution 19: 639-644.

Wijesundara, S., Kathriarachchi, H.S., Ranasinghe, S. W. and Hapuarachchi, G., (2012). Analysis of seed plants of Sri Lanka. In: The National Red List 2012 for Sri Lanka: Conservation Status of the Fauna and Flora, Ministry of Environment, Colombo, Sri Lanka viii+476pp.

Zachos, J.C., Dickens, G.R., Zeebe, R.E. (2008). An early Cenozoic perspective on greenhouse warming and carbon-cycle dynamics. Nature 451: 279-283. 